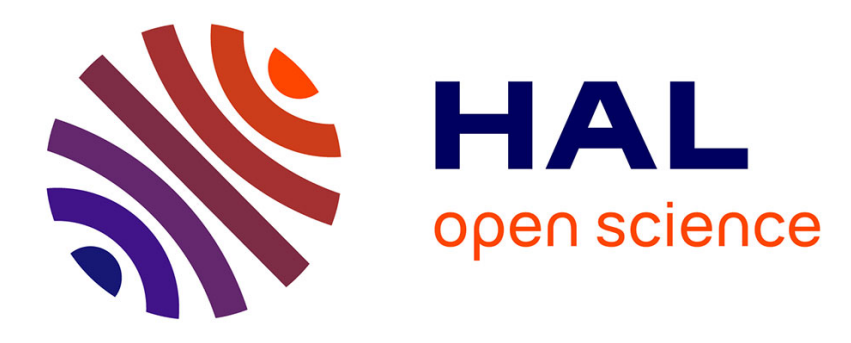

\title{
Climate/growth relationships in a Pinus cembra high-elevation network in the Southern French Alps
}

Saulnier, Edouard, Corona, Guibal

\section{To cite this version:}

Saulnier, Edouard, Corona, Guibal. Climate/growth relationships in a Pinus cembra high-elevation network in the Southern French Alps. Annals of Forest Science, 2011, 68 (1), pp.189-200. 10.1007/s13595-011-0020-3 . hal-00930756

\section{HAL Id: hal-00930756 https://hal.science/hal-00930756}

Submitted on 1 Jan 2011

HAL is a multi-disciplinary open access archive for the deposit and dissemination of scientific research documents, whether they are published or not. The documents may come from teaching and research institutions in France or abroad, or from public or private research centers.
L'archive ouverte pluridisciplinaire $\mathbf{H A L}$, est destinée au dépôt et à la diffusion de documents scientifiques de niveau recherche, publiés ou non, émanant des établissements d'enseignement et de recherche français ou étrangers, des laboratoires publics ou privés. 


\title{
Climate/growth relationships in a Pinus cembra high-elevation network in the Southern French Alps
}

\author{
Mélanie Saulnier • Jean-Louis Edouard • \\ Christophe Corona $\cdot$ Frédéric Guibal
}

Received: 19 April 2010 / Accepted: 30 June 2010 / Published online: 24 February 2011

(C) INRA and Springer Science+Business Media B.V. 2011

\begin{abstract}
-Introduction In the context of climate change, assessing climate-growth relationships is of high importance in order to understand how forest ecosystems evolve and to test climate models at regional scale.

-Objectives This study aims to identify the climate variables that explain most of the variation in Pinus cembra radial growth at different spatial-temporal scales, response functions and moving response functions were processed on chronologies from a dense tree ring network. This original network is centred on the French Alps influenced by the Atlantic, Continental, and Mediterranean synoptic systems.

-Results A spatial clustering pattern matching the latitudinal climatic gradient was observed in tree ring indexed chronologies and climate responses. The stationary response functions computed for each cluster-averaged population evidenced a thermo-dependent northern cluster (Cl1), a rainfall-dependent southern cluster $(\mathrm{Cl} 3)$, and an alternative response for the intermediate cluster in between $(\mathrm{Cl} 2)$. Since the late nineteenth century, the moving response functions indicate an increasing influence of winter precipitation for the northern and the intermediate clusters.
\end{abstract}

Handling Editor: Gilbert Aussenac

M. Saulnier $(\bowtie) \cdot$ C. Corona $\cdot$ F. Guibal

IMEP, UMR 6116 CNRS/Aix-Marseille Université, Bâtiment

Villemin,

Europôle de l'Arbois BP 80,

13545 Aix-en-Provence cedex 4, France

e-mail: melanie.saulnier@etu.univ-cezanne.fr

J.-L. Edouard

Centre Camille Jullian, UMR 6573 CNRS, MMSH,

5 Rue du château de l'Horloge,

13094 Aix-en-Provence cedex 2, France
- Conclusion Considering the increase in temperature and reduction both of summer precipitation predicted by general circulation models and of the snow cover and duration in the French Alps, stone pine is likely to be exposed to stressful conditions during the twenty-first century.

Keywords Dendrochronology · French Alps · Pinus cembra . Climate-growth responses

\section{Introduction}

Treeline ecotones are sensitive to climate variability due to their location at the distribution limit of tree species (Körner 1998). Moreover, human impact on tree growth is supposed to be less severe at high elevation sites, characterised by low stand densities and reduced air pollution. These ecosystems are considered to be of special interest with respect to the environmental changes and are frequently investigated in ecological and palaeocological studies. Swiss stone pine (Pinus cembra L.) is an important coniferous tree species growing in these treeline ecotones in European mountains. Its distribution covers the whole European Alpine chain in Austria, Switzerland, Northern Italy and South-Eastern France. Its elevational distribution stretches from approximately 1800 to $2300-2500 \mathrm{~m}$ in the Southern Alps, and isolated individuals may grow at sites as high as 2 600-2 $700 \mathrm{~m}$ (e.g. Fourchy 1968). This species is well adapted to the harsh environmental conditions and it is able to live as long as 1,000 years (Tranquillini 1979; Petitcolas and Rolland 1998). At high altitude, low temperatures throughout the growing season mainly limit its growth (Tranquillini 1976; Körner 1998; Mayr et al. 2003). For these reasons, it has been widely used in relation to various issues raised by tree ring analyses and particularly in climate-related studies (see Schweingruber (1996) for a review), all the more so as 
its ring-width pattern is rarely affected by growth disturbances due to bark-boring or defoliating organisms such as larch budmoth (Baltensweiler 1993).

During the last decade, in order to study climate-growth relationships, several dendroecological studies have been locally conducted on stone pine in the Western and Eastern Italian Alps (Motta and Nola 1996; Anfodillo et al. 1998; Carrer and Urbinati 2004), in the Austrian Tyrol (Oberhuber 2004; Oberhuber et al. 2008) and in the Northern part of the French Alps (Petitcolas and Rolland 1998). However, to date, only two studies focussing on alpine networks of stone pine tree-ring chronologies have been conducted. They evidenced longitudinal variability in climate-growth relationships (Frank and Esper 2005; Carrer et al. 2007). To our knowledge, no study has taken into account the Oceanic-Mediterranean climatic influences and their possible specific climate-growth relationship. Furthermore, this spatial variability is further complicated by the non-stationary of tree growth response pattern during the last centuries reported by several authors (e.g. Büntgen et al. 2008; Carrer and Urbinati 2006). So this study aims to analyse the effect of these climatic systems on the radial growth of stone pine over the French Alps. We used a dendroecological approach based on a wide network of sites and a very long climate data set for the French Alps to study the growth responses of stone pine to climate variability. Our aims were to (1) assess tree-ring growth patterns of stone pine; (2) identify the climate variables that explain most of the variability in radial growth in each pattern; and (3) study past and current trends in climate-growth relationships.

\section{Material and methods}

\subsection{Study area}

The network consists of 652 individual ring-width series from 38 populations spanning the 1313-2003 period. Sites were chosen to best represent the north-south and westeast gradients $\left(44^{\circ} 06^{\prime} \mathrm{N}\right.$ to $45^{\circ} 53^{\prime} \mathrm{N}, 5^{\circ} 90^{\prime} \mathrm{E}$ to $7^{\circ} 45^{\prime} \mathrm{E}$, Fig. 1) in the French Alps. All sites sampled were in highaltitude (1 935-2 $350 \mathrm{~m}$ a.s.1.) open forest stands with various slope exposures and assumed to be affected by minimal human disturbances.

\subsection{Tree-ring data and dendrochronological analysis}

At each site, 8-29 undamaged dominant or co-dominant standing trees were selected. From each tree, at least two cores were sampled in opposite directions parallel to contour lines approximately $1.30 \mathrm{~m}$ above ground with a Pressler increment borer. In the laboratory, all the cores were fixed to wooden supports and smoothed with a razor blade or by sanding with progressively finer grade sandpaper to optimal surface resolution allowing annual rings to be recognised easily under magnification. All the individual ring widths were measured with an accuracy of $0.01 \mathrm{~mm}$ (Lintab Rinntech ${ }^{\circledR}$ ) and crossdated using TSAPwin scientific programmes.

Indexed chronologies were calculated using ARSTAN (Cook and Holmes 1984) for the purpose of enhancing the climate signal in ring width series. The individual series were first standardised to remove geometric trends in ring width that typically occur due to increasing tree circumference. We fitted a negative exponential curve to the raw data series and divided the measured ring widths by the expected values to obtain dimensionless tree-ring indices. A spline function with a $50 \%$ frequency response of 20 years, which is sufficiently flexible to remove midfrequency variations in tree-ring width, was fitted to individual indexed series and the ratio between measured and expected values computed again. Flexible cubic spline curves can remove both the long-term trend and the effect of localised disturbance events very efficiently, but with some risk of removing possible low-frequency climate information (Cook and Peters 1981; Cook et al. 1990). This process creates stationary time series for each tree with a mean of 1 and homogeneous variance.

Several descriptive statistics commonly used in dendrochronology were computed to compare site chronologies. These included the standard deviation (SD) that estimates the variability of measurements for the whole series and the mean sensitivity (MS) which is an indicator of the mean relative change between consecutive ring-widths. Both SD and MS allow assessment of high-frequency variations in the chronologies (Fritts 1976). The first order serial autocorrelation was computed to detect the persistence retained before and after the standardisation. The expressed population signal (EPS) quantifies the degree to which a particular sample chronology portrays the hypothetically perfect chronology, which may in turn be regarded as the potential climate signal (Wigley et al. 1984). Although a specific range of EPS values cannot be given, Wigley et al. (1984) suggest a threshold of 0.85 as an acceptable statistical quality.

The mean correlation between trees $(r$ bt) was used as a measure of the strength of the common signal (Wigley et al. 1984) in each population. $r$ bt was calculated as a mean correlation between all overlapping pairs of indexed tree series.

\subsection{Spatial pattern analyses}

To further elucidate patterns in the tree-ring network that are expected to reflect the variety of climate influences in the French Alps, a principal component analysis (PCA; Jolliffe 2002) was used as a clustering technique. PCA was successively computed on (1) the tree-ring chronology indices matrix for the period common to all populations (1903-1993) and to (2) the 32 standardised monthly 
Fig. 1 Spatial distribution of the 38 populations. The labelled numbers refer to Table 1

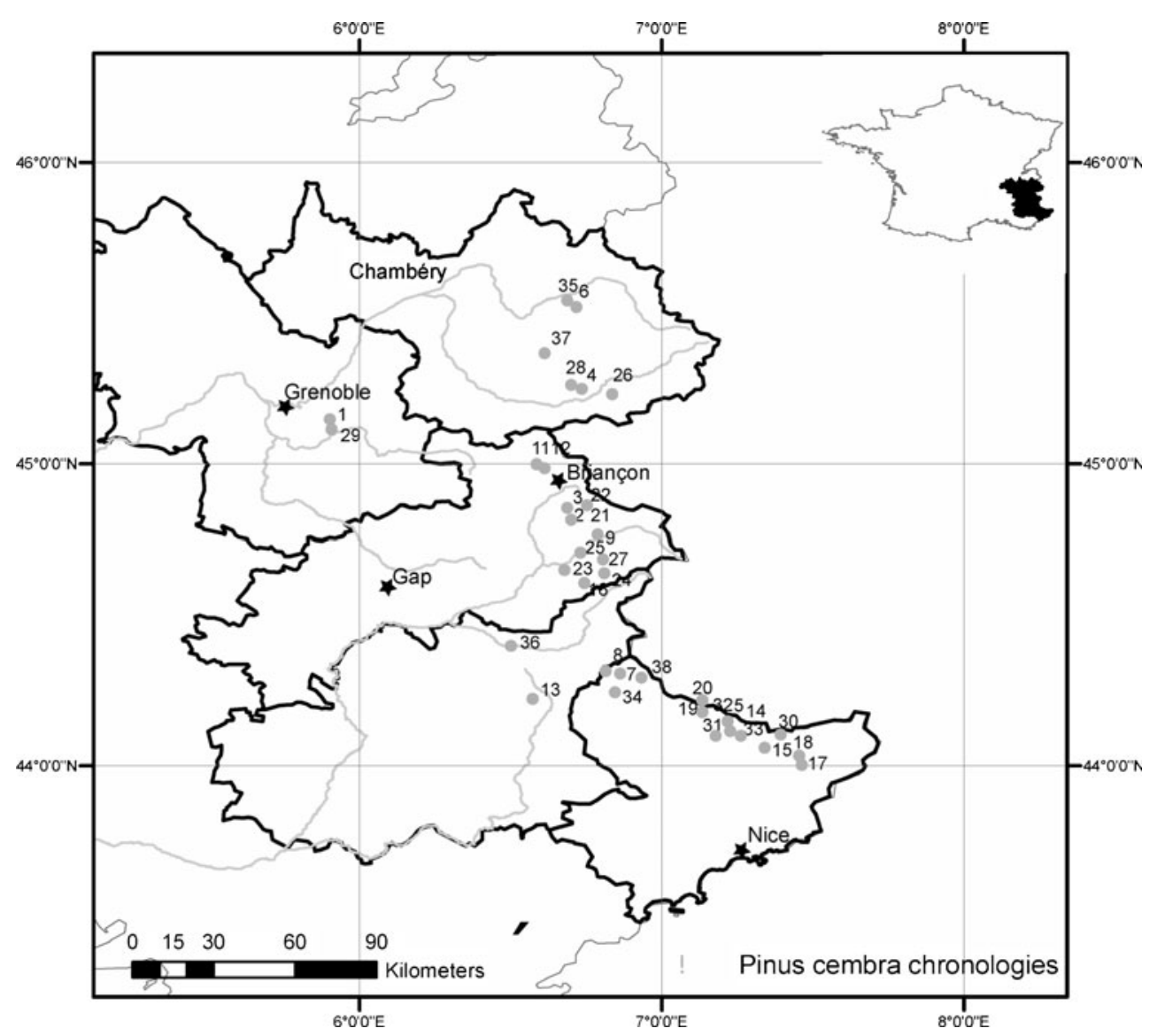

coefficients of the response functions (RF) computed for each population (see details in the following section). This enables us to reduce the variables contained in the three matrices into a new set of variable called principal components (PCs) which are a linear combination of the original variables. These PCs were calculated on the covariance matrix of variables and only the components that expressed at least 5\% of the variability of the original variables were retained (Carrer et al. 2007). These components were rotated according to the Varimax criterion. Varimax rotation is the orthogonal rotation of axes of a subset of unrotated principal components. The normalised varimax method of rotating eigenvectors preserves the orthogonality of the factor loadings but makes them easier to interpret. It makes interpretation easier because original variables often load onto one or, at most, a few factors and each factor typically is represented by a small number of variables. As discussed in detail in Section 3, both PCAs produced three identical clusters and, accordingly, we computed three geographical composite chronologies averaging the indexed series of all trees present at the sites pooled in the same cluster.

\subsection{Climate-growth relationship}

Response function analysis, which is a form of orthogonalized principal component regression, designed to account for the colinearity of monthly climate predictors (Tessier 1989; Serre-Bachet et al. 1991), was used to investigate the climate-tree growth relationship in each cluster. To assess the stationarity nature and consistency of the response function over time, we computed a moving response function (MRF). Statistical calibrations between ringwidth series and monthly climatic data variables were tested for temporal changes by applying the software package DENDROCLIM2002 (Biondi and Waikul 2004) that computes bootstrapped response and correlation functions for single and multiple intervals. RF and MRF were processed using the indexed chronologies. Both for RF and MRF, the above detailed climatic data set included mean monthly temperature and precipitation from June ${ }_{t-1}$ to September ${ }_{t}$, i.e. 32 predictors. Coefficients are computed between ring indices and climate variables over several months before the growing season because ring-width integrates climatically influenced processes occurring over a longer period (Fritts 1976). MRF are based on progressively shifting the period of a fixed number of years across time to compute the response coefficients. To provide a sufficient number of degrees of freedom, the length of the window period was at least twofold longer than the number of predictors (32), i.e. only 100 -year periods were considered.

$\mathrm{RF}$ and MRF produce a temporal set of coefficients for each monthly predictor, whereby statistical signifi- 
cance at $P<0.05$ was tested using a bootstrap procedure (Guiot 1991; Biondi and Waikul 2004; Oberhuber et al. 2008).

\subsection{Meteorological data}

The Histalp dataset based on 192 precipitation and 132 temperature stations throughout the Alps was used to study climate-growth relationships. This dataset subjected to homogeneity tests and relative adjustments, to spatial and temporal analyses, is gridded, respectively, on a $0.1 \times 0.1^{\circ}$ network for precipitation and on a $1 \times 1^{\circ}$ network for temperature (Auer et al. 2007). We preferred these data rather than those available from individual weather stations because of the lack of long meteorological series in the French Alps. Given the high climate variability in the Alps, especially for precipitation, the climate-growth relationships are computed with the closest grid points to each population. In the case of clusters, the $n$ weighted grid were averaged to create a regional data set for the three regions. Temperature and precipitation monthly data from 1800 to 2004 were expressed as anomalies.

\section{Results}

\subsection{Chronology descriptive statistics}

Locations and descriptive statistics of the 38 tree-ring site chronologies are summarised in Table 1 . These series were obtained from 652 mature stone pine trees. The estimated mean tree ages per site (at coring height) vary from 76 to 394 years. Mean sensitivity and first order serial autocorrelation range from 0.15 to 0.22 and from 0.68 to 0.91 , respectively. High first-order autocorrelation indicates that radial growth throughout the network is strongly influenced by conditions prevailing in the preceding year and by the geometrical effect of increasing stem circumference. The mean autocorrelation decreases from 0.8 to 0.162 after standardisation which evidences the efficiency of the standardisation. A particularly useful parameter for assessing chronology quality is the interseries correlation $\left(r_{\mathrm{bt}}\right)$ which varies from 0.260 to 0.563 . All chronologies have high EPS values $(>0.94)$ suggesting a strong common signal related to environmental climatic factors.

None of these statistics displayed a significant correlation with respect to sample size, altitude, longitude or latitude. For example, Gord 1 (a southern population) and Sjaqu (a northern population) have a mean sensitivity equal to 0.16 . Conversely, Brai (a southern population) and Tueda (a northern population) have a high mean sensitivity. Neither of these statistics displayed a clear trend with respect to latitude, longitude or altitude and no significant pattern was detected with PCA analyses (not presented here).

\subsection{Multivariate analysis}

PCA on tree-ring growth indexes and monthly coefficients of the response functions showed that the variances accounted for by $\mathrm{PC} 1$ are, respectively, $16 \%$ and $17 \%$. They are both $12 \%$ for PC2 (Fig. $2 \mathrm{a}, \mathrm{b}$ ). From the maps of the weightings on $\mathrm{PC} 1$, spatial clustering and latitudinal gradients are evidenced (Fig. 3a, b). The correlations between these weightings and the site latitudes are respectively 0.77 and 0.68 , and are significant $(p<0.05$, Fig. 2c, d). For PCA on the tree-ring growth indexes, PC1 has the highest weightings from the chronologies located in the southern French Alps with diminishing weightings from intermediate and Northern populations. For PCAs on the monthly coefficient of the response functions, weightings on PC1 have a reversed pattern with highest weightings in the Northwestern portion of the network and lowest weightings towards the southeast. The patterns do not appear clearly with PC2.

These results yielded significant discrimination of three clusters of population related to spatial distribution which were confirmed by $K$ means clustering (Carrer et al. 2007):

- C11: the eight northernmost populations in the outer regions of the Alps (Moyenne-Tarentaise and HauteMaurienne);

- $\mathrm{Cl2}$ : the 17 intermediate eastern populations in the inner regions of the Alps (Briançonnais-Queyras);

- $\mathrm{Cl3}$ : the 13 southernmost populations (Mercantour).

Hence, the 38 populations were gathered in three clusters and their ring-width chronologies were averaged in order to analyse climate-growth relationships at regional scale.

\subsection{Climate forcing of radial growth}

Response function coefficients depicted in Fig. 4 show similar profiles in the three identified clusters. Temperature in August $_{t-1}$ and March $_{t}$ temperature are inversely related to radial growth. A positive response is also evidenced with August $_{t-1}$ precipitation. However, slight differences are observed between the three clusters. $\mathrm{Cl} 2$ and $\mathrm{Cl} 3$ show a positive relation with summer temperature (July $\left.{ }_{t}\right)$ and would appear to be particularly winter rainfall-dependent with significant positive relations with winter precipitation with regards to 2 months. $\mathrm{Cl1}$, on the other hand appears as more thermo-dependent exhibiting a positive relation with October $_{t-1}$, May and August $_{t}$ temperature.

RFs adequately assess the year-to-year climate-growth responses of stone pine, but are unable to detect changes over time. We examined long-term variability of climategrowth relationships in ring-width chronologies of stone pine by means of MRF coupled with a very long meteorological series. 


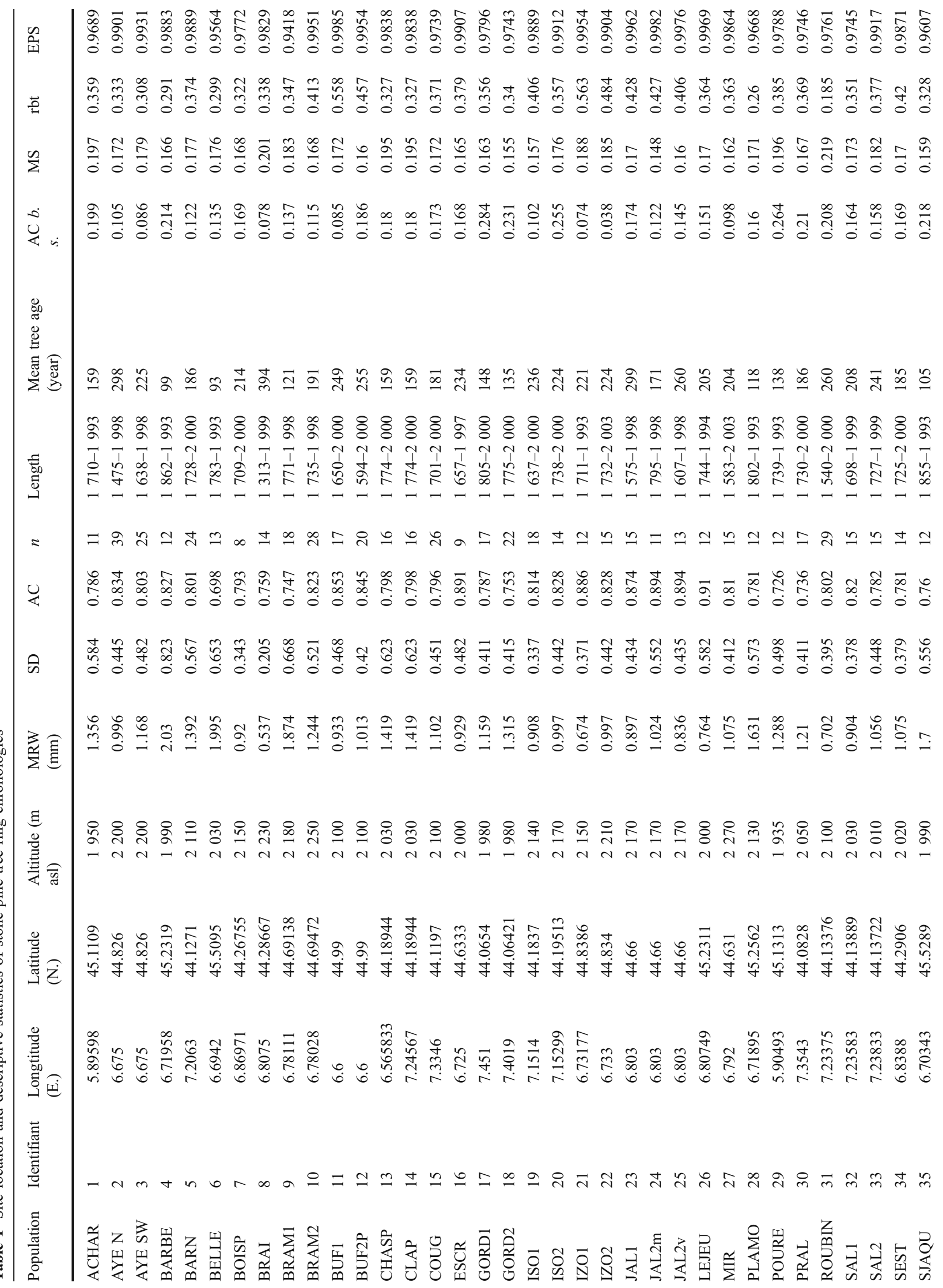




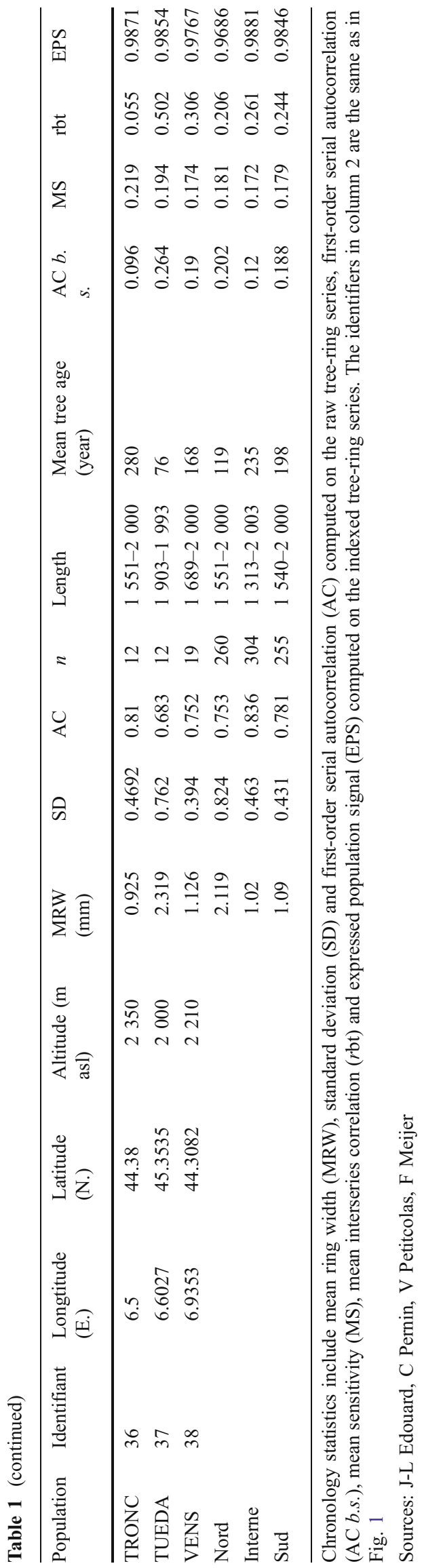

\subsection{Evolution of the climate-growth relationships}

Temporally stable and unstable key climate variables were uncovered by comparing results of MRF (Fig. 5). Each of three main factors evidenced by the RFs, i.e. negative relations with August $t_{t-1}$ and $\operatorname{March}_{t}$ temperature and positive relation with August $t_{t-1}$ precipitation, all appeared stable throughout the last two centuries. In detail, MRF(s) show similar trends in $\mathrm{Cl} 2$ and $\mathrm{Cl} 3$. They evidence the stability of the positive relation with winter precipitation (December $_{t-1}$ and January ${ }_{t}$ ) over the whole period. With regard to temperature, $\mathrm{MRF}(\mathrm{s})$ display an increasing influence of June ${ }_{t}$ and $\mathrm{July}_{t}$ temperature for both clusters. Finally, Cl1 shows a distinct pattern of change reflecting the influence of temperature throughout the 200-year period. The July ${ }_{t}$ and August ${ }_{t}$ temperatures revealed an increasing positive influence since the late nineteenth century. Concerning precipitation for $\mathrm{Cl} 1$, the MRF reveal an increasing influence of December $_{t-1}$ since the late nineteenth century.

\section{Discussion}

4.1 Similarities with previous dendroclimatological studies

Results of RF and MRF revealed that radial growth of stone pine for the last two centuries was primarily driven by temperature during summer ${ }_{t}$, August ${ }_{t-1}$, March $_{t}$, and precipitation in December $t_{t-1}$. These results are consistent with several alpine studies that aimed to identify key climatic parameters explaining radial growth by means of RF and MRF (Urbinati et al. 1997; Petitcolas and Rolland 1998; Carrer et al. 2007; Oberhuber et al. 2008).

These similarities show that stone pine react in the same way to a common external factor such as climate. They are explained by the physiology of the stone pine and seem to be independent of the spatial variability. During the growth period, high summer temperature promotes faster leaf, shoot and stem growth (Tranquillini 1979). Recent studies in the Central European Alps have demonstrated that radial stem growth is limited by low summer temperature (Büntgen et al. 2005; Carrer and Urbinati 2004; Frank and Esper 2005; Oberhuber 2004). The negative relation with August ${ }_{t-1}$ temperature, also noticed by Petitcolas and Rolland (1998) and Oberhuber et al. (2008), is generally related to restricted root growth and/or depleted reserves storage. Anfodillo et al. (1998) reported that soils at the treeline in the North Eastern Italian Alps could become physiologically dry during the growing period and that high temperature and vapour pressure deficits have a negative effect on the photosynthesis of stone pine hence limiting reserves storage. 

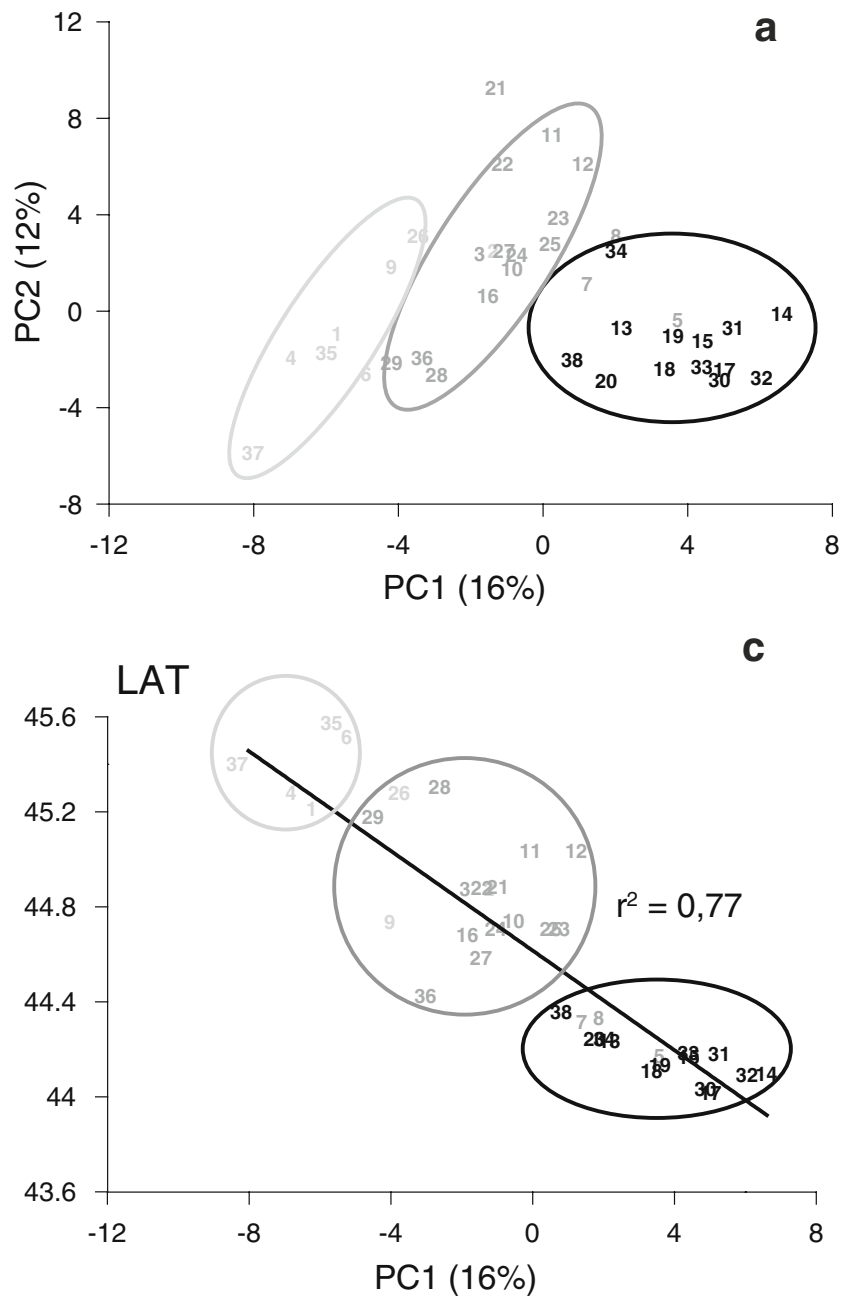

Fig. 2 Scatter plots of weighting coefficients for PC1 and PC2 (a, b) and relationships between weighting coefficients for PC1 with site latitude $(\mathbf{c}, \mathbf{d})$. Weighting coefficients are calculated considering treering indexed chronologies (a, c) and climate-growth relationships

During the dormant period, the negative influence of warm conditions in March $_{t}$ might be explained by an increase in respiration which consumes the carbohydrate reserves. The snow layer increases albedo (Tranquillini 1979) and intensifies the effect of sunshine on carbohydrate depletion. According to Wieser et al. (2005), the total estimated $\mathrm{C}$ loss of stone pine during the dormancy period amounted to $9 \%$ of the annual net photosynthetic $\mathrm{C}$ gain, and it takes a month to compensate this loss. These respiratory $\mathrm{C}$ losses due to high temperature could explain this relationship between March $t$ temperature and tree growth (Carrer et al. 2007).

Warm winter increases the frequency of wet snow events, winter thaw and even snow-free periods, and probably the number of freezy-thaw cycles and, hence, the risks of embolism (Mayr et al. 2003). Winter dessication can occur throughout late winter and early spring when water losses by cuticular transpiration cannot be compen-
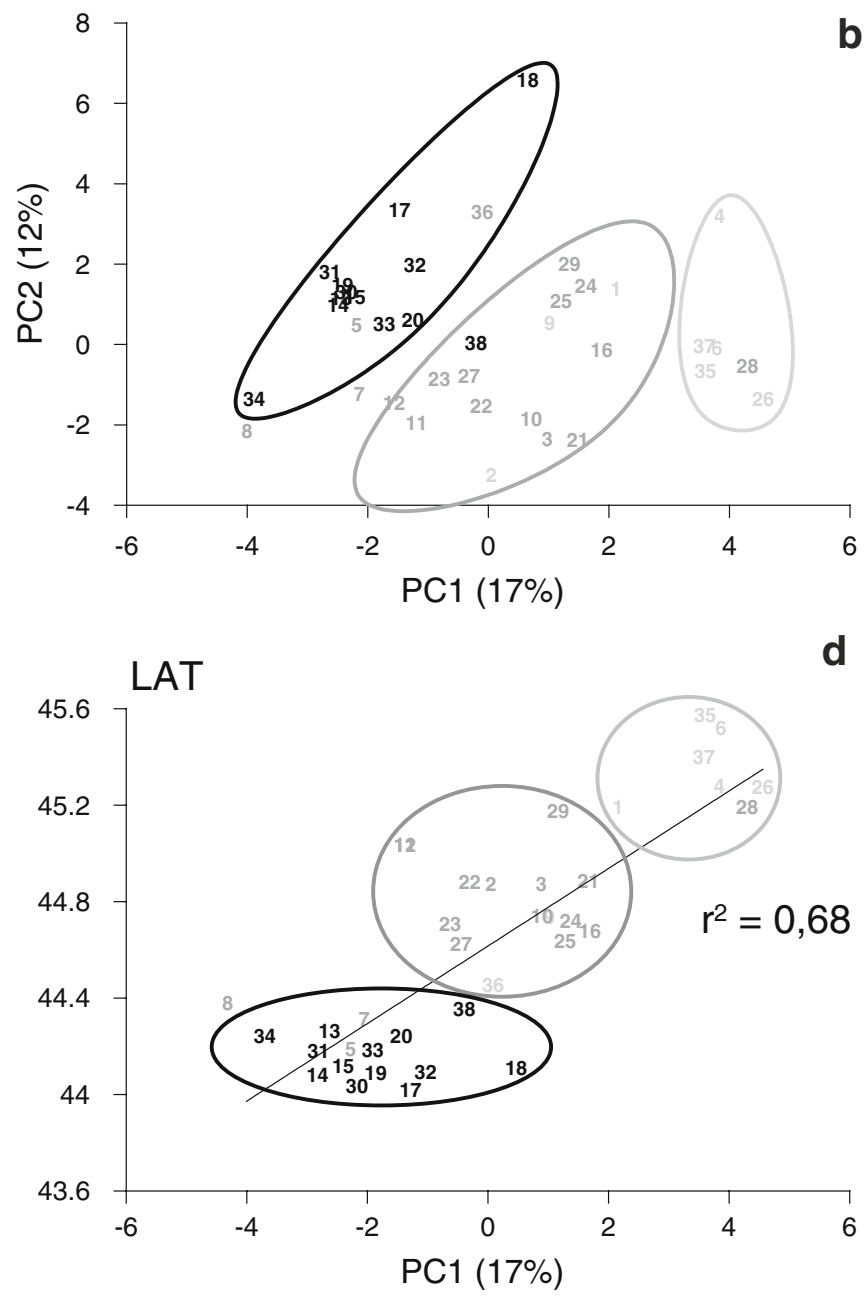

expressed by the monthly correlation function coefficients (b, d). Axis labels report the percentage of variance expressed by each component. Labelled numbers refer to Table 1. Number and ellipse colours are related to clusters; light grey $\mathrm{Cl1}$, grey $\mathrm{Cl} 2$ and black $\mathrm{Cl} 3$

sated due to frozen soil and limited reserves in the aboveground tissues (Havranek and Tranquillini 1995; Tranquillini 1979, 1982).

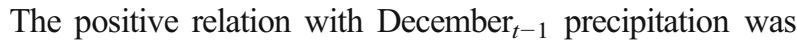
also observed in the Italian Eastern Alps (Urbinati et al. 1997; Anfodillo et al. 1998) and in the Tyrol (Oberhuber et al. 2008). It can be interpreted as a positive but delayed action on ring-width. Indeed, at high altitude, from mid-November the trees progressively come into dormant phase. At this time, trees are totally inactive with a negative $\mathrm{CO}_{2}$ balance (Tranquillini 1979). Early snowfalls induce a thick snow layer which prevents deep soil freezing so that a $10-\mathrm{cm}$ snow layer is enough to protect soil from frost and diminish detrimental effects of winter desiccation (Oberhuber 2004). Moreover snow, which is easily trapped by groups of five needles, insulates shoot extremities and buds (Tranquillini 1979). Lastly, winter precipitation constitutes a water reserve for subsequent growth season. This point is discussed in next section. 
Fig. 3 Map of weightings of tree site indexed chronologies and climate-growth relationships expressed by the monthly correlation function coefficients on varimax-rotated PC1.

Weightings of site indexed chronologies on PC1 (a). Weightings of monthly correlation function coefficients on PC1 (b)
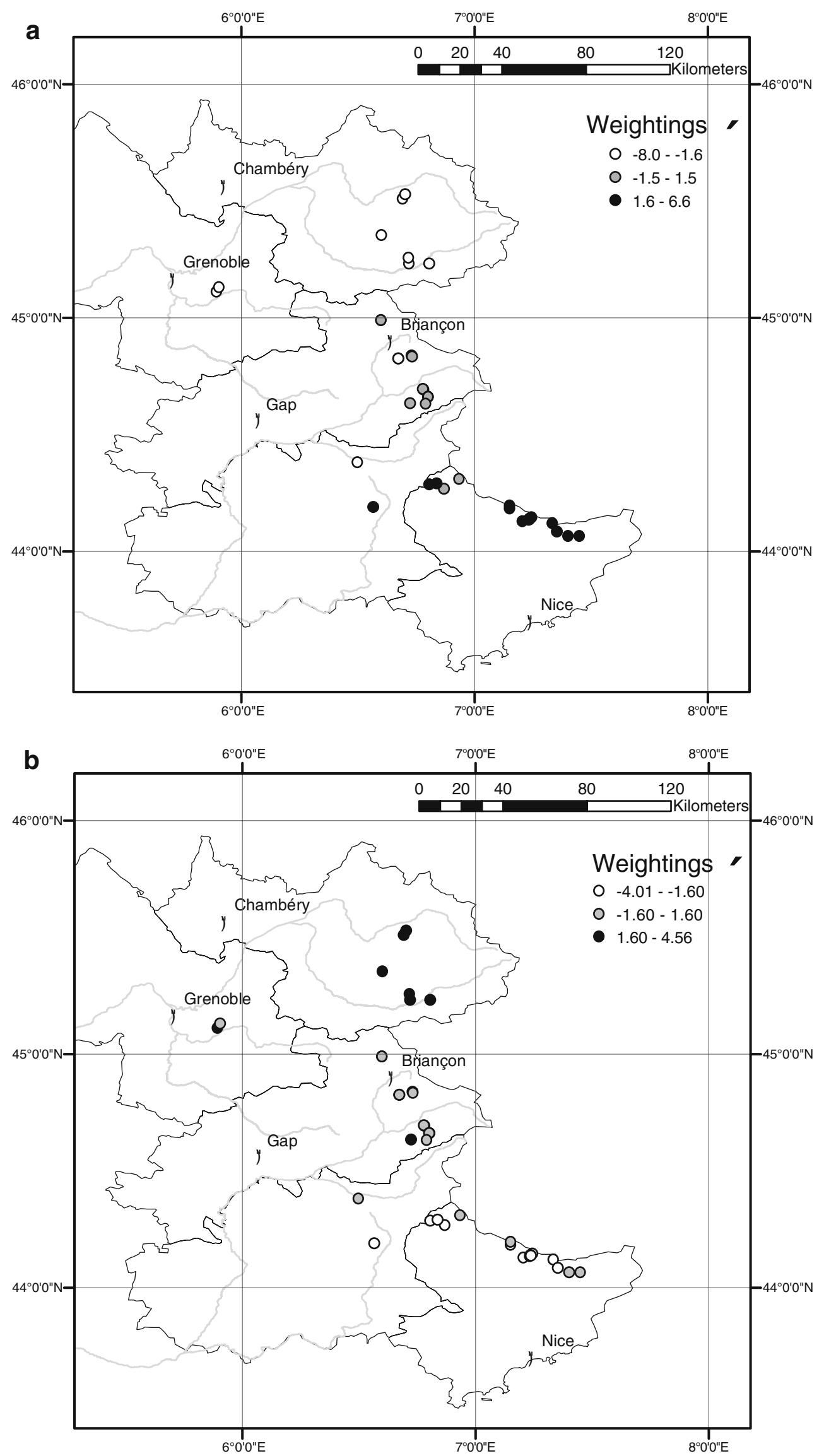
Fig. 4 Response function analysis between residual chronologies and monthly mean temperature and precipitation. Highlighted band in dark grey indicates significant relationships at $P=0.05$, with dark grey a significant relationship for all groups, medium grey for Central and Southern groups only and light grey for only one group. The dashed line represents the $90 \%$ significance level

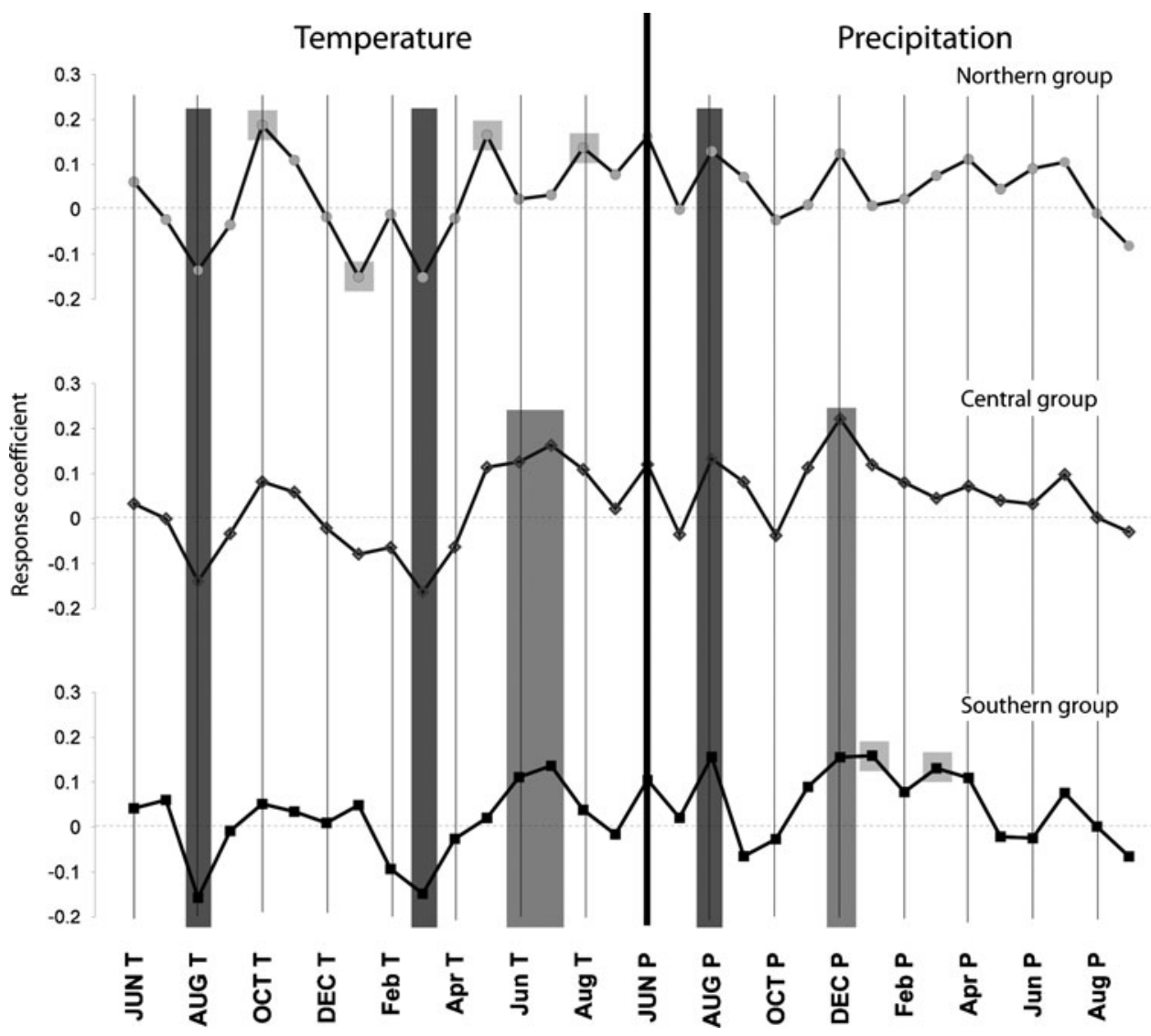

\subsection{The major influence of the latitudinal gradient}

On the one hand, statistical parameters revealed no particular spatial pattern which suggests that stone pine has a uniform mechanism to respond to the many environmental factors influencing tree-ring growth at different sites throughout the French Alps. Carrer et al. (2007) already demonstrated this behaviour for this species.

On the other hand, the results of the two PCAs, carried out on indexed tree-ring chronologies and their climate response pattern, exhibit clear clusters arranged along a latitudinal gradient. Furthermore, the split threshold values for the three clusters, around $45^{\circ} \mathrm{N}$ and $44.5^{\circ} \mathrm{N}$ in latitude, match the usual latitudinal bioclimatic zonation described for the French Alps (Ozenda 1985). Cl1 aggregates series located in the northern part of the outer regions of the French Alps subject to continental influences. $\mathrm{Cl} 3$ is essentially composed of series from the southern region influenced by the Mediterranean climate system. In between, $\mathrm{Cl} 2$ aggregates series located in a transitional area subject to both Mediterranean and Continental influences (Ozenda 1985). This aggregation confirms the well-known capacity of stone pine to retain evidence of regional climate in its tree-ring growth series (Motta and Nola 1996; Urbinati et al. 1997; Oberhuber 2004). The few intracluster differences present in tree-ring growth patterns and responses to climate are probably related to (1) local weather variability; (2) different biophysical conditions caused by soil moisture, solar radiation, snowmelt dynamics and growing season length; and (3) forest stand history, age structure and possible local disturbances.

Winter precipitation appears as the discriminating variable for tree growth in $\mathrm{Cl} 3$. This winter rainfall dependence is related to the relatively drier summer conditions in this southernmost area of the Alps making stone pine particularly sensitive to delayed snowmelt that provides an essential reservoir for water storage in these high-elevation shallow and coarse-textured soils (Carrer et al. 2007). Cl1, for its part, evidences a positive relation with autumn $n_{t-1}$ temperature as shown by previous studies in the Northeastern, Central and Eastern Alps (Petitcolas and Rolland 1998; Carrer et al. 2007; Oberhuber et al. 2008). This specific response is probably linked to the capacity of stone pine to photosynthesise until November (Wieser et al. 2009).

\subsection{Varying influences of climate over time}

When interpreting the MRF, Carrer et al. (2007) emphasise that the temporal step-wise increase or decrease of significance in growth sensitivity towards some climatic 
Fig. 5 Monthly precipitation and temperature effects on treering growth using moving response function with a 100 -year time window (represented in all cases by the labels on the $x$ axis). The $y$-axis represents the results of MRF. Dark grey represents MRF for Southern cluster, medium grey for Central cluster and light grey for Northern cluster. The dashed line represents the $90 \%$ significance level

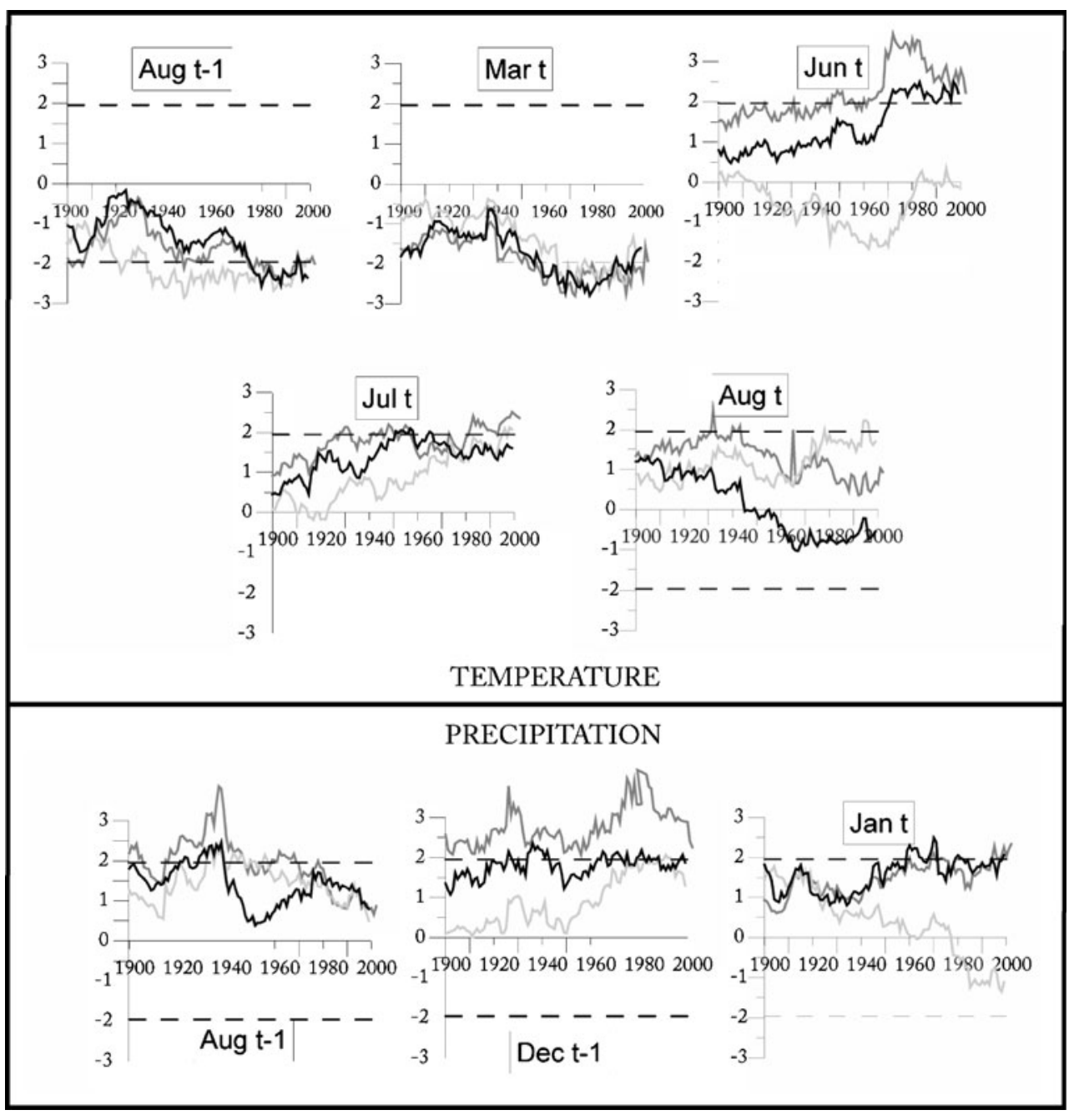

variables may reflect the influence of other occurring factors (e.g. habitat change, increased $\mathrm{CO} 2$ atmospheric concentration, nitrogen deposits).

MRF revealed that $\mathrm{Cl} 1$ has been reacting similarly to $\mathrm{Cl} 3$ since the late nineteenth century with a significantly $(p>0.05$, Fig. 5) increasing influence of winter precipitation in the Northern Alps. This changing sensitivity may be related to most frequent water stresses due to the temperature increase leading to the reduction of snow cover and duration. Indeed, precipitation and snow are characterised in the French Alps by a marked declining northeast-southwest gradient. However, Martin and Etchevers (2005) pointed out that snow cover height and duration decreased at Col de Porte (Massif de la Chartreuse, Northern Alps) during 1961-2001 by approximately $35 \%$ and 1 month. Furthermore, the result of the simulation performed with the model SAFRANCROCUS shows that the snow cover height decreases faster in the Northern than in the Southern French Alps (Martin and Etchevers 2005). The increasing negative influence of March $_{t}$ temperature tends to confirm this hypothesis since high temperatures favour early melting of snow and exposes trees to late frost, frequent at this season and at this altitude. It also could be explained by the effects on respiration processes and carbon losses (Wieser et al. 2005).

In addition to that, the intensified positive relation between Cl1 and July ${ }_{t}$ and August $t_{t}$ temperatures clearly evidences a time lag with $\mathrm{Cl} 2$ and $\mathrm{Cl} 3$ related to the late onset of the growing season in the Northern Alps. In Cl1, the stone pine growth period starts in $\mathrm{May}_{t}$ and ends in August ${ }_{t}$, while the growth period in $\mathrm{Cl} 2$ spans 3 months starting in June . In addition, the whole duration of growth in $\mathrm{Cl} 3$ is concentrated in July $_{t}$ and since the middle of the nineteenth century in June $_{t}$. That could support the hypothesis of an extension of the growing period in the Northern Alps since the midnineteenth century as shown by other studies and related to climate warming (e.g. Menzel et al. 2006).

\section{Conclusion}

This study is the first dealing with long-term relationships between radial growth and climate throughout the whole of 
the French Alps. Stone pine growth appears to vary significantly at annual time scale and these changes are mostly driven by climatic factors. Summer temperatures and winter precipitation mainly affect both the growing season length, carbon and site water balance of the stone pine as previously observed in the Alpine Chain. However, these limiting factors vary spatially and temporally throughout the French Alps, influenced by the latitudinal gradient. The Southern cluster evidenced by means of the PCA is usually more sensitive to winter precipitation because of the impact of more acute water stress due to the influence of Mediterranean air condition, while the Northern cluster is more sensitive to summer temperature. Similar to the Southern cluster as regards precipitation, the Central cluster differs by the positive relation with summer temperature. These influences have been noticeable throughout the whole of the French Alps since the end of the nineteenth century.

From a dynamic point of view, the MRF reveals that climate change especially affects the Northern populations in two opposite ways. On the one hand, the increasing influence of July $t_{t}$ temperature supports the hypothesis of warmer summer temperature promoting faster leaf and shoot growth and cambial activity. On the other hand, the increasing influence of winter precipitation on tree growth appears as a mean to prevent water stress impact during the growth period. Considering the increase of temperature in the twenty-first century as predicted by General Circulation Models (IPCC 2007) and the concomitant reduction of snow cover duration, stone pine will encounter worsening conditions. In addition to that, considering the decrease of summer precipitation predicted by IPCC report, the populations of the southern cluster will probably face enhanced summer water stress.

Acknowledgements This work was supported by the project ESCARSEL (ANR-06-VULN-010), founded by the French ANR "Vulnérabilité: milieux et climat", and the Parc Naturel Regional du Queyras and Parc National du Mercantour. Thanks are due to V. Petitcolas and Fleur-Meijer who made, respectively, ten and one chronologies available. Precipitation and temperature data were provided by the HISTALP project. We are deeply grateful to I. Auer for providing us with the latest revised version of the dataset. We also thank two anonymous referees who improved the earlier version of this manuscript.

\section{References}

Anfodillo T, Carrer M, Rento S, Urbinati C (1998) Long and short term growth dynamics of Picea abies (L.) Karst, Larix decidua (Mill.), Pinus cembra (L.) and climatic factors: first results of an integrated study at the timberline in eastern Italian Alps. Ecology 29:253-259

Auer I, Bohm R, Jurkovic A, Wolfgang L, Orlik A, Potzmann R, Schoner W, Ungersbock M, Matulla C, Briffa K, Jones P, Efthymiadis D, Brunetti M, Nanni T, Maugeri M, Mercalli L, Mestre O, Moisselin JM, Begert M, Müller-Westermeier G,
Kveton V, Bochnicek O, Stastny P, Lapin M, Szalai S, Szentimrey T, Cegnar T, Dolinar M, Gajic-Capka M, Zaninovic K, Majstorovic Z, Nieplova E (2007) HISTALP-historical instrumental climatological surface time series of the Greater Alpine Region. Int J Climatol 27:17-46

Baltensweiler W (1993) Why the larch bud-moth cycle collapsed in the subalpine larch-cembran pine forests in the year 1990 for the first time since 1850? Oecologia 94:62-66

Biondi F, Waikul K (2004) DENDROCLIM2002: a C++ program for statistical calibration of climate signals in tree-ring chronologies. Comput Geosci 30:303-311

Büntgen U, Esper J, Frank DC, Nicolussi K, Schmidhalter M (2005) A 1052-year tree-ring proxy for Alpine summer temperatures. Clim Dyn 25:141-153

Büntgen U, Frank DC, Wilson R, Carrer M, Urbinati C, Esper J (2008) Testing for tree-ring divergence in the European Alps. Glob Chang Biol 14:2433-2453

Carrer M, Urbinati C (2004) Age-dependent tree-ring growth response to climate in Larix decidua and Pinus cembra. Ecology 85(3):730-740

Carrer M, Urbinati C (2006) Long-term change in the sensitivity of tree-ring growth to climate forcing in Larix decidua. New Phytol 170:861-871

Carrer M, Nola P, Edouard JL, Motta R, Urbinati C (2007) Regional variability of climate-growth relationships in Pinus cembra high elevation forests in the Alps. J Ecol 95:1072-1083

Cook ER, Holmes RL (1984) Program ARSTAN user manual: laboratory of tree ring research. University of Arizona, Tucson

Cook ER, Peters K (1981) The smoothing spline: a new approach to standardizing forest interior tree-ring width series for dendroclimatic studies. Tree-Ring Bull 41:45-53

Cook ER, Briffa K, Shiyatov S, Mazepa V (1990) Treering standardization and growth-trend estimation. In: Cook ER, Kairiukstis LA (eds) Methods of dendrochronology. Kluwer Academic Publishers, Dordrecht, pp 104-123

Fourchy P (1968) Notes sur le pin cembro dans les Alpes françaises. Revue Forestière 20(2):77-94

Frank D, Esper J (2005) Characterization and climate response patterns of a high-elevation, multi-species tree-ring network in the European Alps. Dendrochronologia 22:107-121

Fritts HC (1976) Tree rings and climate. Academic Press, London, $567 \mathrm{pp}$

Guiot J (1991) The bootstrapped response function. Tree-Ring Bull $51: 39-41$

Havranek W, Tranquillini W (1995) Physiological processes during winter dormancy and their ecological significance. In: Smith WK, Hinckley TM (eds) Ecophysiology of coniferous forests. Acacemic Press, San Diego, pp 95-124

IPCC (2007) Regional climate projections. In: Solomon S, Qin D, Manning M, Chen Z, Marquis M, Averyt KB, Tignor M, Miller HL (eds) Contribution of working group I to the fourth assessment report of the Intergovernmental Panel on Climate Change, climate change 2007: the physical science basis. Cambridge University Press, Cambridge, p 996

Jolliffe IT (2002) Principal component analysis. Springer, New York

Körner C (1998) A re-assessment of high elevation of tree line positions and their explanation. Oecologia 115:445-459

Martin E, Etchevers P (2005) Impact of climatic change of snow cover and snow hydrology in the French Alps. In: Huber UM, Bugmann HKM, Reasoner MA (eds) Global change and mountain regions (a state of knowledges overview). Springer, Dordrecht, pp 235-242

Mayr S, Schwienbacher F, Bauer H (2003) Winter at the alpine timberline. Why does embolism occurs in Norway Spruce but not in stone pine? Plant Physiol 131:780-792

Menzel A, Sparks TH, Estrella N, Koch E, Aasa A, Ahas R, Kübler K, Bissolli P, Braslavska O, Briede A, Chmielewski FM, Crepinsek Z, Curnel Y, Dahl A, Defila C, Donnelly A, Filella Y, Jatczak K, 
Mage F, Mestre A, Nordli Ø, Penuelas J, Pirinen P, Remisova V, Scheifinger H, Striz M, Susnik A, Van Vliet AJH, Wielgolaski FE, Zach S, Zust A (2006) European phenological response to climate change matches the warming pattern. Glob Chang Biol 12(10):1969-1976

Motta R, Nola P (1996) Dendrochrono-ecological signal in three stone pine (Pinus cembra L.) chronologies from theWestern Italian Alps. Dendrochronologia 14:43-57

Oberhuber W (2004) Influence of climate on radial growth of Pinus cembra within the alpine timberline ecotone. Tree Physiol 24:291-301

Oberhuber W, Kofler W, Pfeifer K, Seeber A, Gruber A, Wieser G (2008) Long-term changes in tree-ring-climate relationships at Mt. Patscherkofel (Tyrol, Austria) since the mid-1980s. Trees 22:31-40

Ozenda P (1985) La végétation de la chaîne alpine dans l'espace montagnard européen. Masson (eds.). Paris. p 331

Petitcolas V, Rolland C (1998) Comparaison dendroécologique de Larix decidua Mill., Pinus cembra L. et Pinus uncinata Mill. ex Mirb. dans l'étage subalpin du Briançonnais (Hautes-Alpes, France). Ecology 29:305-310

Schweingruber F (1996) Tree rings and environment. dendroecology. Birmensdorf, Swiss Federal Institute for Forest,Snow and Landscape Research. Haupt, Berne, Stuttgart, Vienna

Serre-Bachet F, Martinelli N, Pignatelli O, Guiot J, Tessier L (1991) Evolution des températures du Nord-Est de l'Italie depuis
1500 A.D. Reconstruction d'après les cernes des arbres. Dendrochronologia 9:213-229

Tessier L (1989) Spatio-temporal analysis of climate tree-ring relationships. New Phytol 11:517-529

Tranquillini W (1976) Water relations and alpine timberline. Ecological studies. Springer Verlag, Berlin, pp 153-169

Tranquillini W (1979) Physiological ecology of the alpine timberline. Springer Verlag, Berlin, $137 \mathrm{pp}$

Tranquillini W (1982) Frost drought and its ecological significance. In: Lange OL, Nobel PS, Osmond CB, Ziegler H (eds) Encyclopedia of plant physiology, new series, vol. 12B. Springer Verlag, Berlin, pp 379-400

Urbinati C, Carrer M, Sudiro S (1997) Dendroclimatic response variability of Pinus cembra L. in upper timberline forests of Italian Eastern Alps. Dendrochronologia 15:101-117

Wieser G, Gigele T, Pausch H (2005) The carbon budget of an adult Pinus cembra tree at the alpine timberline in the Central Austrian Alps. Eur J For Res 124(1):1-8

Wieser G, Matyssek R, Luzian R, Zwerger P, Pindur P, Oberhuber W, Gruber A (2009) Effects of atmospheric and climate change at the timberline of the Central European Alps. Ann For Sci 66:402-413

Wigley TM, Briffa KR, Jones PD (1984) On the average value of correlated time series, with applications in dendroclimatology and hydrometeorology. J Clim Appl Meteor 23:201-213 